Neurosurg Focus 28 (4):E11, 2010

\title{
The role of radiosurgery in the treatment of craniopharyngiomas
}

\author{
Anand Veeravagu, M.D., ${ }^{1}$ Marco Lee, M.D., Ph.D., F.R.C.S., ${ }^{1,2}$ Bowen Jiang, B.S., ${ }^{3}$ \\ and Steven D. Chang, M.D. ${ }^{1}$ \\ ${ }^{1}$ Department of Neurosurgery, Stanford University School of Medicine, Stanford, California; \\ ${ }^{2}$ Department of Neurosurgery, Santa Clara Valley Medical Center, San Jose, California; \\ ${ }^{3}$ Stanford University School of Medicine, Stanford, California
}

\begin{abstract}
The treatment of craniopharyngiomas is composed of an intricate balance of multiple modalities. Resection and radiotherapy have been combined to synergistically control tumor growth while preventing undue harm to crucial neurovascular structures. Although a craniopharyngioma is a benign lesion pathologically, it may induce severe neurological injury due to its location and rate of growth. More recently, the advent of targeted, fractionated radiotherapy has allowed for more aggressive tumor control while reducing the necessity for large resections. Initial studies have demonstrated significant tumor control in patients who are treated with resection combined with radiation therapy, versus surgery alone, with a lower rate of treatment-associated neurological deficits. In this review, a detailed account of the current studies evaluating the role of stereotactic radiosurgery in the management of craniopharyngiomas is presented. The authors also provide a short account of their experience to aid in defining the role of CyberKnife radiosurgery. (DOI: 10.3171/2010.2.FOCUS09311)
\end{abstract}

\section{KeY Words • craniopharyngioma • radiosurgery • CyberKnife • Gamma Knife}

$\mathrm{C}$ RANIOPHARYNGIOMAS are benign extraaxial epithelial tumors that arise from squamous epithelial remnants of the Rathke pouch, near the pituitary gland. ${ }^{46}$ These cells may extend from the nasopharynx to the tuber cinereum and may arise within the sphenoid bone, the sella, or the suprasellar region. Although craniopharyngiomas are rare, they are the most common suprasellar tumor in the pediatric age group, accounting for as many as $5 \%$ of all intracranial tumors or up to $10 \%$ of pediatric brain tumors. ${ }^{72}$ The incidence of craniopharyngioma has been estimated to be approximately 1.5 per million people per year, ${ }^{7,31}$ but may be considerably higher in specific ethnic groups, such as Japanese children (5.25 per million) ${ }^{50}$ Craniopharyngiomas have a bimodal age distribution, generally appearing in young patients between the ages of 5 and 14 years and in adults between 50 and 74 years.

Although they are histologically benign, craniopharyngiomas can cause severe and often permanent damage to nearby hypothalamic, visual, and endocrine apparatus. The presentation of these tumors may include symptoms

\footnotetext{
Abbreviations used in this paper: $\mathrm{BED}=$ biologically equivalent dose; $\mathrm{CGE}=$ cobalt Gy equivalent; GK = Gamma Knife; GTR = gross-total resection; PFS = progression-free survival; SRS = stereotactic radiosurgery; $\mathrm{STR}=$ subtotal resection; $\mathrm{VFD}=$ visual field deficit.
}

related to endocrine derangement of the hypothalamicpituitary axis, with severity dependent upon location, size, and rate of growth. Mass effect from hypothalamic-pituitary axis dysfunction may result in increased intracranial pressure presenting as headache, nausea, and vomiting. Cases with large mass lesions may also present with hydrocephalus (noted more commonly in children than in adults) as a result of the obstruction of the cerebral aqueduct or the interventricular foramina. ${ }^{25,39} \mathrm{Com}-$ pression of the nearby optic chiasm typically results in VFDs such as hemianopia and papilledema. Endocrine disruption often manifests as amenorrhea, hypothyroidism, and diabetes insipidus. ${ }^{24,28}$

The structural composition of these tumors may include solid, cystic, mixed solid and cystic, or calcified components. Traditionally, craniopharyngiomas have been separated into either the adamantinomatous or papillary variety. More commonly observed in the pediatric population, the adamantinomatous type is characterized as calcified with mixed composition. Papillary craniopharyngiomas observed in adults are often more solid.

Current treatment strategies for craniopharyngiomas include cystic drainage, intracavity chemotherapy, limited resection or GTR, and radiation therapy. These strategies are often combined into a patient-specific treatment plan based on age at presentation, tumor size, relation to optic chiasm and third ventricle, presence of hydrocepha- 


\section{A. Veeravagu et al.}

lus, and degree of pituitary endocrinopathy. If total excision can be safely performed with minimal risk to these structures, then surgery remains the treatment of choice because it allows rapid decompression, minimizes recurrence, and provides a histological diagnosis. However, judgment of minimal risk is often unclear as some favor STR coupled with adjunctive therapy to achieve similar outcomes. $918,34,35,38,43,80,82,92$ Although surgical approaches are often curative, they can produce high treatment-related morbidity and even death due to the close proximity of crucial neurovascular structures. Recurrent craniopharyngiomas must be considered separately, because secondary surgery is associated with a higher risk of complications and a lower cure rate. ${ }^{8,18,21,29,57,87}$ More recently, SRS techniques have become increasingly used as either a primary or secondary treatment for patients with craniopharyngioma.

\section{Surgical Outcomes}

Complete resection of craniopharyngiomas is a primary objective and has curative potential. In a recent patient series studied by Shi et al., ${ }^{77} 284$ patients (58 children) were treated surgically with no adjunctive therapy between 1996 and 2006. Gross-total resection, STR, and partial removal of the tumors was achieved in 237 (83.5\%), 34 (12.0\%), and 13 patients (4.5\%), respectively. Upon follow-up, 23 patients $(14.1 \%)$ experienced recurrence 1.0 to 3.5 years after GTR, and 24 (64.9\%) tumors recurred $0.25-1.5$ years after STR or partial resection. In this series, the early mortality rate was $4.2 \%$. In another 25-year retrospective study by Van Effenterre and Boch, ${ }^{85}$ 122 patients underwent either GTR (59\%), STR (29\%), or partial resection (12\%). During the follow-up period, 29 patients (24\%) experienced 1 or more recurrences. The delay to recurrence ranged from 1 to 180 months (mean 42 months, median 12 months). In this study, $13 \%$ of patients in whom a GTR was achieved experienced tumor recurrence; $33 \%$ with STR experienced recurrence; and $69 \%$ with partial removal suffered a recurrence of tumor. Radiotherapy was not systematically administered and was only reserved for cases of recurrence. The surgical mortality rate was $2.5 \%$, and overall patient survival was $95 \%$ at 2 years, $91 \%$ at 5 years, and $83 \%$ at 10 years.

The comparison of surgical complications for craniopharyngiomas across various patient series produces a variable picture. Most of the recent large patient series report a GTR rate of 59 to $90 \% .^{18,33,85,89}$ The 10 -year recurrence-free survival rates have been reported as 74 to $81 \%$ for GTR, $, 1,19,8741$ to $42 \%$ after partial removal, ${ }^{32,69}$ and 83 to $90 \%$ after a combination of surgery and radiotherapy. ${ }^{32,69}$ Surgical mortality rates in these series vary between 1.1 and $4.2 \% .^{18,76,85,89}$ It is well documented that recurrent tumors are associated with significantly higher risk and poorer outcome, with overall mortality rates reported to be between 10.5 and $40.6 \% .^{18,89}$ Pituitary dysfunction may occur in 50 to $100 \%$ of patients, with diabetes insipidus as the most common dysfunction. Visual deterioration may occur in up to $50 \%$ of patients undergoing GTR for craniopharyngiomas. ${ }^{45}$

\section{Radiation Therapy}

Although surgical drainage or resection of craniopharyngiomas may be the initial step in management, the rate of complete obliteration is low using only 1 modality. The fine balance between further neurological deficit and complete tumor resection has led to the use of various noninvasive forms of therapy. Radiation therapy is often applied during the postoperative course in the event of STR or tumor recurrence. Frequently, external radiation therapy is the preferred strategy, but in recent years endocavitary/intracavitary radiation and SRS have also demonstrated efficacy in tumor control.

\section{Proton Beam Radiotherapy}

Proton beam radiotherapy, a specific form of conformal external beam therapy, is used as an adjuvant and/or salvage treatment modality for craniopharyngiomas, particularly those in the pediatric population. In a retrospective study by Luu and colleagues ${ }^{53} 16$ patients (ages 7-34 years) were treated with proton beam radiation. A daily dose of 1.8 CGE was used for a total CGE of 50.4 to 59.4. Local tumor control was achieved in 14 patients with few acute side effects. The authors reasoned that if the dose to the optic pathway was kept below $55 \mathrm{CGE}$, the rate of complication would be $<10 \%$ with minimal damage to the optic apparatus. In a similar study by Fitzek et al., ${ }^{22} 15$ patients with craniopharyngioma were treated with combined proton-photon irradiation at a median dose of 56.9 CGE. The actuarial 10-year survival rate was $72 \%$ and the 10 -year local control rate was $85 \%$. Two patients suffered visual defects (hemianopia and total loss of vision) after receiving doses of 64 and 55.3 CGE, respectively, to their optic chiasm.

\section{Endocavitary Radiation Therapy}

Endocavitary/intracavitary irradiation with a betaemitter $\left({ }^{186} \mathrm{Re},{ }^{32} \mathrm{P},{ }^{198} \mathrm{Au}\right.$, or $\left.{ }^{90} \mathrm{Y}\right)$ or an antitumoral antibiotic (bleomycin) can be used to treat purely cystic, or cystic components, of craniopharyngiomas. ${ }^{15}$ This treatment modality requires the use of stereotactic technique to achieve intracystic instillation of radioactive agents. In a recent retrospective study of endocavitary irradiation $\left({ }^{186} \mathrm{Re}\right)$ treatment by Derrey et al., ${ }^{15}$ complete cystic resolution was achieved in 17 (44\%) of 48 patients treated and partial resolution in another 17 patients (44\%). Visual function improved in 12 patients while baseline endocrine function was preserved. Similarly, Julow and colleagues ${ }^{42}$ observed an $80 \%$ reduction in 47 patients and complete disappearance of the cyst in 27 patients within 1 year after treatment with intracystic colloidal ${ }^{90} \mathrm{Y}$. Across several studies, the response rate of tumors to endocavitary/intracavitary irradiation is 71 to $88 \% .^{67,88}$ However, because intracavitary irradiation is limited to cystic tumors, recurrence and survival rates using only this type of therapy are considered inferior to those of surgery or external radiotherapy ${ }^{36,88}$ Additionally, the risk of visual deterioration is considerable, possibly due to unpredictable radiation dose to the optic pathway and radiation damage from leakage. In a review by Cáceres, ${ }^{7}$ the numbers of patients experiencing no change or improvement in visual acuity 


\section{Radiosurgery in the treatment of craniopharyngiomas}

after intracavitary irradiation ranged from 42 to $99 \%$ of the different series, whereas 31 to $58 \%$ experienced deterioration in visual function.

\section{External Radiation Therapy}

Fractionated radiation therapy improves craniopharyngioma control and survival ${ }^{23,49,56,65,69,74}$ and is the standard treatment for residual or recurrent tumor. Most patient series demonstrate that when combined with STR, adjuvant radiotherapy allows for greater tumor control and survival than surgery alone. ${ }^{30,32,70,71,79,86}$ In a study by Varlotto et al., ${ }^{86}$ an $89 \%$ tumor control rate was noted in patients who received both STR and external beam irradiation. Stripp and colleagues ${ }^{79}$ compared 57 patients treated only with surgery to 18 patients treated with STR combined with radiation therapy, and demonstrated a 10 -year tumor control rate of 42 and $84 \%$, respectively. The case for using primary radiation therapy for recurrent craniopharyngioma is even stronger, showing a lower risk of recurrence $(30 \%)$ and better outcome $(90 \%, 10$ year PFS). ${ }^{41,43,44,62}$ Finally, Karavitaki and colleagues ${ }^{45}$ examined the records of 121 patients and subdivided the patients into 4 treatment categories: GTR, GTR with radiotherapy, partial removal, and partial removal with radiotherapy. The recurrence-free survival rate was $100 \%$ at 10 years in the GTR only and GTR with radiotherapy groups, 38\% in the partial removal group, and $77 \%$ in the partial removal with radiotherapy group.

When using radiotherapy, the risk of neurotoxicity from radiation injury should be considered alongside gains in potential tumor control. Doses of 50-60 Gy are most commonly used. ${ }^{86}$ Conventionally fractionated focal radiation therapy around the sellar-suprasellar region is also associated with risks similar to surgery. Disruption of the hypothalamic-pituitary axis may result in diabetes insipidus, panhypopituitarism, hypogonadism, hypotha-

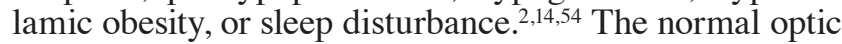
apparatus is particularly sensitive to radiation; optimized dose and fractionation regimes carry a $3 \%$ risk of optic neuropathy. ${ }^{20,55,63}$ There is also considerable discussion about the effect of radiation on cognitive function, an issue particularly pertinent in the pediatric population. Additionally, radiation itself carries the risk of secondary malignancies, ${ }^{5,73,83}$ radiation necrosis, ${ }^{37,83}$ and vasculopathy, which also have secondary neurodegenerative effects.

Typically, craniopharyngiomas are treated with radiation doses between 45 and $55 \mathrm{~Gy}$ in 1.8 to 2 Gy fractions to prevent growth of tumor and minimize injury to the visual pathways. Long-term (10-year) local control ranges from 31 to $42 \%$ with surgery alone compared with 57 to $89 \%$ with surgery and radiotherapy. ${ }^{30,32,69,71,79,86}$ However, there are limitations, as the wide treatment field includes irradiating many structures, such as the optic apparatus, pituitary gland, hypothalamus, and medial temporal lobe. The risk may only manifest itself after a long delay, but this issue is particularly important because benign conditions such as craniopharyngiomas confer favorable longterm survival and have a predilection for the pediatric population. Another limitation of radiation therapy is that when conventional radiotherapy fails, it almost inevitably precludes further radiotherapy treatment to the recurrent tumor. Finally, although of minor importance, conventional fractionated radiotherapy usually takes place over a 6-week course, which is less attractive to patients when compared with other shorter treatment courses. For these reasons, radiosurgery (particularly multisession radiosurgery) may present a more practical option, especially for treating those tumors surrounding the optic apparatus.

\section{Stereotactic Radiosurgery}

Stereotactic radiosurgery is a relatively recent therapeutic option for craniopharyngioma that has significantly improved the effectiveness of, and morbidity associated with, radiation therapy. With SRS, 1 to 5 radiation treatments are used to treat residual or recurrent lesions. The application of stereotaxis for target localization, treatment planning, and daily treatment immobilization allows for a more precise delivery of radiation dose, with a steeper dose gradient between tumor and parenchymal tissue to prevent further neurological deficit. The radiation dose can be delivered using either a multiple cobalt- 60 gamma radiation-emitting source such as the GK or a modified linear accelerator (CyberKnife). Most stereotactic systems can deliver a radiation beam to within approximately $1 \mathrm{~mm}$ of the lesion. Historically, SRS for craniopharyngiomas was limited to tumors $3 \mathrm{~cm}$ or less in size that were 3 to $5 \mathrm{~mm}$ away from the optic chiasm and nerves. In the case of single-session SRS, the optic chiasm becomes a limiting anatomical structure capable of only receiving 8 to $10 \mathrm{~Gy}$ per session before the incidence of optic neuropathy increases. ${ }^{27,51}$ More recent multisession SRS using image-guided radiosurgical techniques has allowed for treatment of craniopharyngiomas immediately adjacent to the anterior visual pathways. ${ }^{1}$

In the current literature, several studies have reported safe and effective long-term results with the application of SRS using the GK for the treatment of craniopharyngiomas. ${ }^{10,48,75,84}$ Kobayashi et al. ${ }^{47}$ published the largest treatment and outcomes series, involving 98 cases. At a mean marginal dose of 11.5 Gy and a mean tumor size of $3.5 \mathrm{~cm}^{3}$, these authors observed a tumor control rate of $79.6 \%$, with a complete response in $19.4 \%$ and partial response in $67.4 \%$ of the cases. The actuarial 5- and 10 -year survival rates were 94.1 and $91 \%$, respectively, with respective PFS rates of 60.8 and $53.8 \%$. Also within the last year, Yomo and colleagues ${ }^{90}$ demonstrated the outcomes in 18 patients with residual or recurrent craniopharyngioma who were treated using the Leksell GK Model C. Tumor growth was controlled in 17 cases (94\%), and volume reduction was attained in 13 cases $(72 \%)$. Mean tumor volume was $1.8 \mathrm{~cm}^{3}$ and the mean marginal radiation dose was 11.6 Gy. No new endocrinopathy was observed and 3 patients experienced substantial improvement of visual functions following shrinkage of the neoplasm. In another study by Chung et al., ${ }^{11}$ tumor control was achieved in $87 \%$ of the 31 patients in the study, and $84 \%$ demonstrated fair to excellent clinical outcomes. Minniti et al. ${ }^{58}$ completed a large meta-analysis of 8 published studies that included 252 patients who underwent either unfractionated radiosurgery or GK therapy, demonstrating a tumor control rate of $69 \%$. Taken together (Table 1), the published studies on GK therapy for craniopharyngiomas 
A. Veeravagu et al.
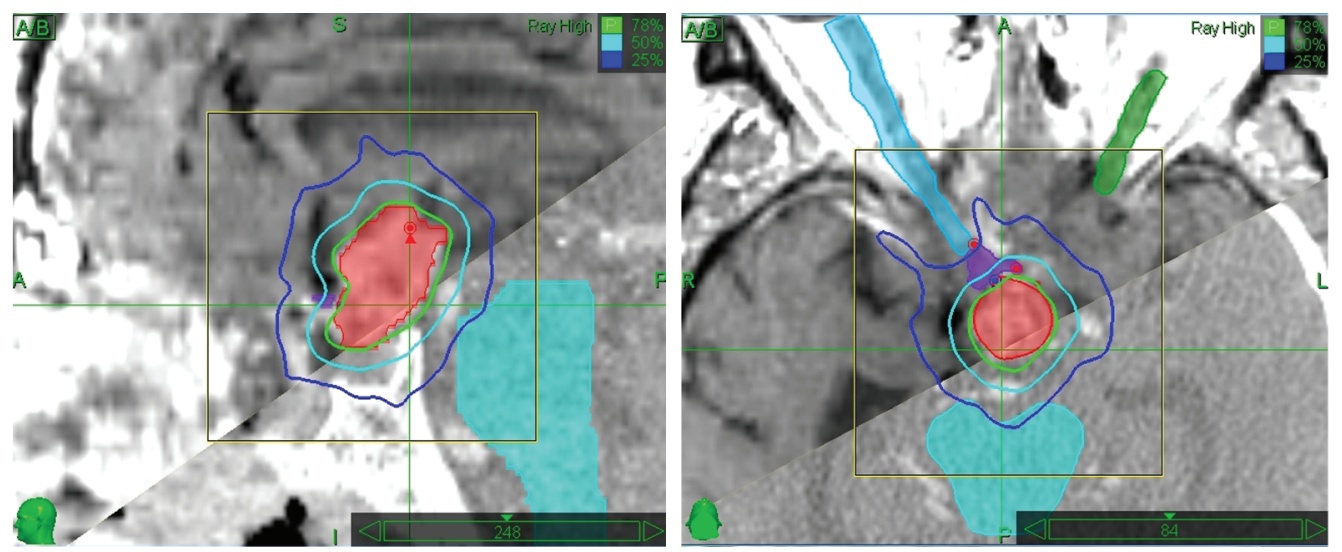

Craniopharyngioma

Right Optic Nerve

Left Optic Nerve

Optic Chiasm

Brain Stem

Fig. 1. Sagittal (left) and axial (right) CT/MR fusion planning images. Left: Area of targeted therapy and isodose lines are demonstrated. Right: Area of suspected tumor with regions of anatomical importance, including right optic nerves and brainstem, are shown.

demonstrate an average control rate of $90 \%$ for solid tumors, $88 \%$ for cystic tumors, and $60 \%$ for mixed tumors. Tumor control was achieved with a mean marginal dose of 12 Gy and recurrence of tumor was observed in $85 \%$ of cases that received a marginal dose $<6 \mathrm{~Gy}$.

Given the current advances in image-guided radiosurgical technology, the principle of multisession delivery of SRS can be incorporated with the anatomical precision and conformality of radiosurgery. This incorporation allows for the precise delivery of potentially safer radiation doses than encountered in single session radiosurgery, while exploiting the volume effect by applying higher and more effective doses than was possible using conventional radiation therapy. The multisession delivery approach is particularly pertinent in treating craniopharyngiomas, which are often located near delicate neurovascular structures. The tolerance of these critical structures to radiation depends on the amount of radiation received, volume of tissue irradiated, previous insult, and prior radiotherapy. Due to the proximity of the tumors to the optic apparatus, only a single dose of 8 to $10 \mathrm{~Gy}$ is tolerable to avoid damage to the nearby structures. ${ }^{36}$ Higher doses to optic nerves are associated with increasing rates of deficit. Leber et al. ${ }^{51}$ reported that optic neuropathy occurred in 22 patients $(26.7 \%)$ who received 10 to 15 Gy and 13 patients $(78 \%)$ who received $>15 \mathrm{~Gy}$, whereas 31 patients who received $<10$ Gy were without optic insult. Likewise, Stafford and colleagues ${ }^{78}$ observed radiation optic neuropathy in $1.7 \%$ of patients who received $<8 \mathrm{~Gy}$, in $1.8 \%$ of patients who received $8-10 \mathrm{~Gy}$, and in $6.9 \%$ of patients who received $>12$ Gy after treatment with the GK for benign tumors of the sellar or parasellar region.

\section{Cyberknife SRS: Our Experience}

The CyberKnife (Accuray, Inc.) consists of a miniature lightweight linear accelerator mounted on a robotic arm with $6^{\circ}$ of freedom of movement. This configuration allows unobstructed access to the entire body and a photon beam can be targeted with submillimeter accu$\operatorname{racy}^{64}$ (Fig. 1). The CyberKnife employs an image-guided control loop with target tracking capabilities, thus it can adjust for patient movement and obviates the use of invasive frames to stabilize the patient. Patients do wear a thermoplastic mask that can be used for multisession SRS (hypofractionation) in patients with tumors near eloquent structures, allowing higher doses of radiation to be delivered over a longer period of time.

In a study by Lee et al., ${ }^{52} 11$ patients with residual craniopharyngiomas within $2 \mathrm{~mm}$ of the optic apparatus or pituitary gland were treated using the CyberKnife SRS system. The clinical presentation, surgical history, radiation received, and outcome of these 5 male and 6 female patients with an average age of 34.5 years are documented in Table 2. A mean marginal dose of 21.6 Gy prescribed to a mean isodose line of $75 \%$ was applied over multiple sessions. The mean maximum dose was $29.9 \mathrm{~Gy}$ and the mean target volume was $6 \mathrm{~cm}^{3}$ (Table 3). Patient outcomes were quantified using MR imaging and formal Goldman visual field assessments at 6-month intervals for 2 years, then once every year (Table 4). Prior to CyberKnife therapy, 10 patients suffered from a degree of visual loss, while 5 had endocrine abnormalities requiring hormonal replacement. Ten patients had operative reports documenting an STR with radiological confirmation, and 1 underwent a complete resection with follow-up MR imaging demonstrating recurrence 1 year after surgery. Residual tumor was most often located in the suprasellar region, and in 10 cases was found to be against or displacing the optic nerve or chiasm. The pituitary stalk only was compressed in 1 patient.

The mean follow-up time was 15.4 months (range 4-64 months). All 10 patients with visual field or acuity problems either improved or remained stable after CyberKnife radiosurgery. In this series, treatment plans were designed to keep the dose experienced by the optic apparatus to $<5$ Gy during any single session. The volume of the optic apparatus that received $80 \%$ of the prescribed dose was $<0.05 \mathrm{~cm}^{3}$, whereas the volume that received $50 \%$ of the dose was $<0.5 \mathrm{~cm}^{3}$. Therefore, the actual volume of the optic segment that received $5 \mathrm{~Gy}$ would be small relative to the total volume of the optic apparatus. Preservation of baseline visual function is supported by our previous work, which showed that the risk 


\section{Radiosurgery in the treatment of craniopharyngiomas}

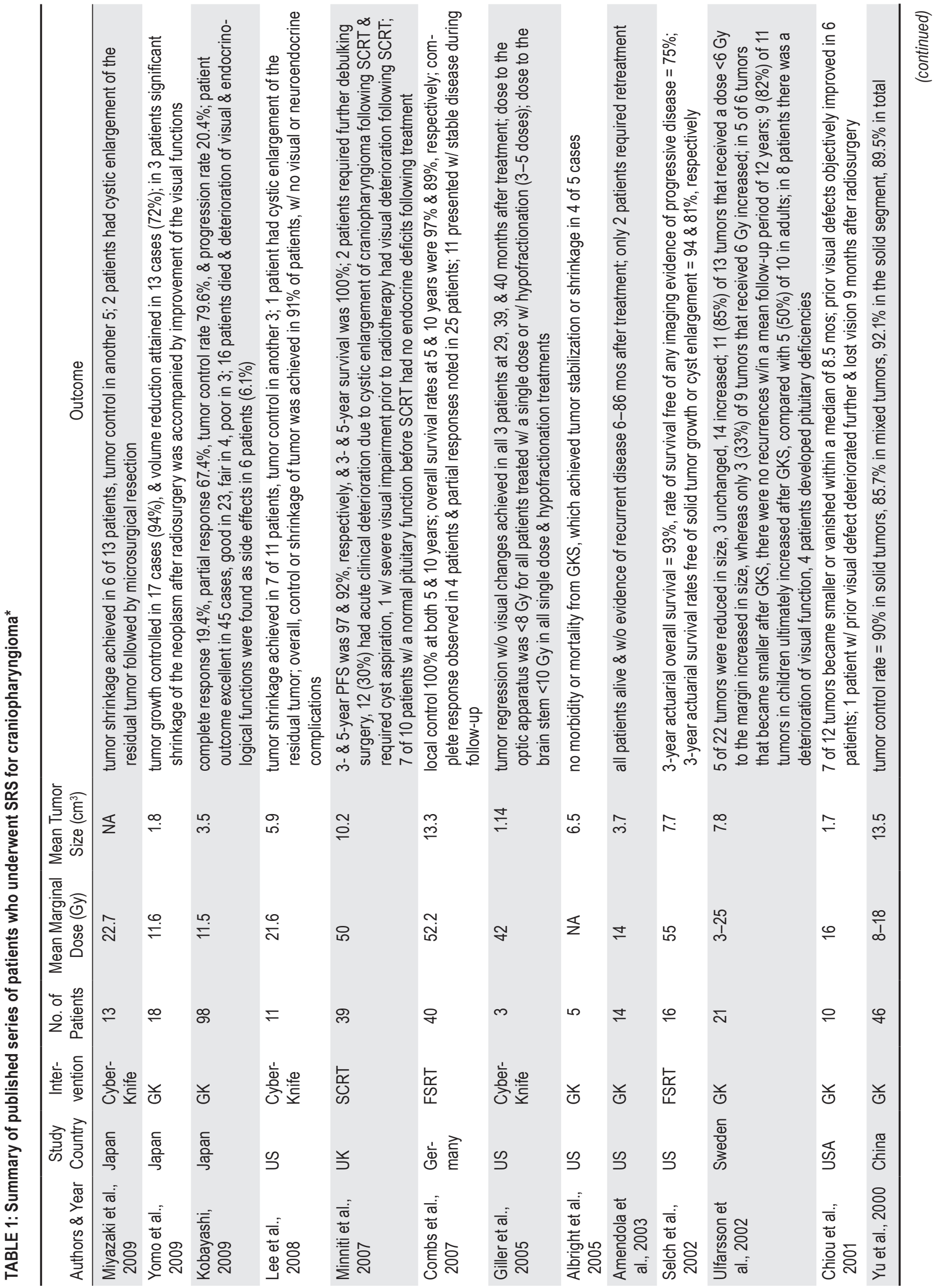




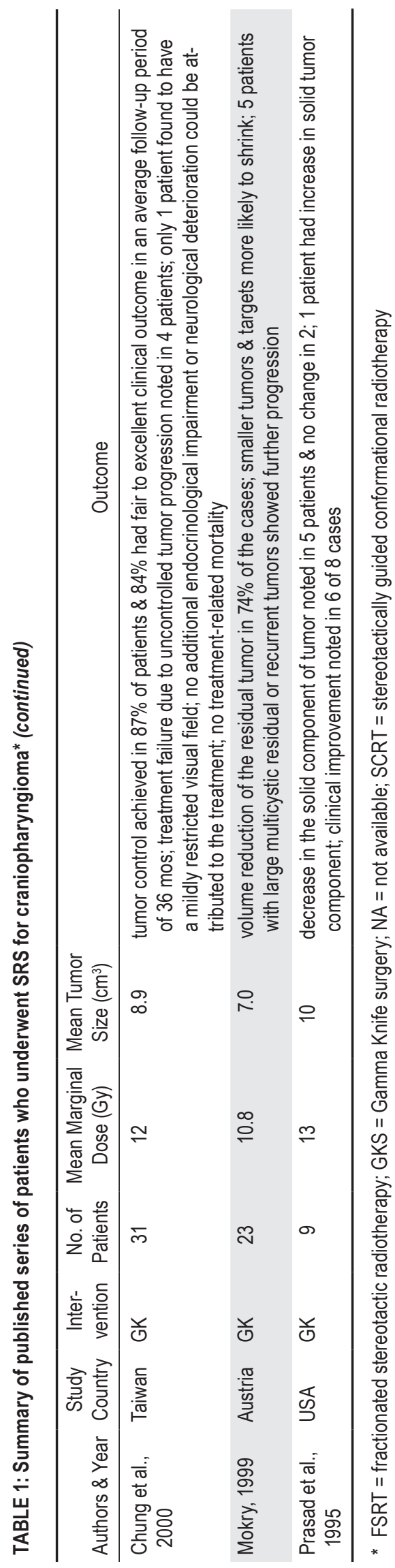

of visual loss with multisession radiosurgery appears to be low for perioptic tumors. ${ }^{1,66}$ Radiation-induced optic neuropathy is a known entity that tends to present over the course of several years, but the short follow-up duration of our study prevents making definitive conclusions regarding the effect of multisession therapy.

There were no new neuroendocrine problems and the 5 patients with endocrine derangement remained stable, with no new deterioration after CyberKnife treatment. Tumor shrinkage was observed in 7 patients, with 3 of these tumors remaining the same at 2 years after treatment, resulting in a $91 \%$ tumor control rate. One patient developed a cystic enlargement of the residual tumor without any worsening symptoms or signs. Irradiation of cystic craniopharyngiomas may result in cystic enlargement, which does not represent tumor recurrence and may later regress. ${ }^{13}$ In our series, the patient's symptoms remained stable, but rigorous clinical and radiological assessment is critical, including visual and neuroendocrine assessment. We believe that multisession treatment regimens minimize the risk to the optic apparatus and pituitary gland while delivering an appropriate amount of radiation for disease control.

There are several assumptions that contributed to dosimetry calculations for stereotactic radiation delivery. In a review by Timmerman et al., ${ }^{81}$ the authors outlined 3 requirements necessary for a successful treatment: 1) the ability to describe the location of the target; 2) the ability to shape the prescription isodose surface to the surface of the target volume; and 3) the ability to construct radiation dose distributions with very rapid fall-off dose to spare surrounding healthy tissue. In calculating dosimetry, the best approach is to have multiple beam directions, which allows for attenuation of the primary beam outside of the targeted areas using multileaf collimators.

\section{Radiosurgical Dosing}

Several factors influence the choice of radiosurgical dose, including the pathology of the lesion, the nature of the adjacent tissues, and the volume of both of these structures. Much of what we know about the tolerance of normal brain structures came from studies using conventional radiation therapy and single fraction radiosurgery. As discussed, the CyberKnife, with its frameless platform, allows for multisession schedules. Multisession radiation allows sublethal injury to normal tissue, which can repopulate between fractions; other advantages include achieving higher tumor cell death by reoxygenation of hypoxic cells, and reassortment of cells into sensitive phases of the cell cycle.

To estimate the BED of different fractionation schemes, the linear quadratic model of cell survival from radiation is used. ${ }^{40}$ Multifraction treatments were converted to a single-fraction BED using the linear quadratic model:

$$
\mathrm{BED}=\mathrm{nd}[1+\mathrm{d} /(\alpha / \beta)]
$$

where $n$ represents the number of fractions, $d$ represents dose per fraction, and $\alpha / \beta$ represents the alpha/beta ratio. ${ }^{16}$ The ratio of $\alpha / \beta$ reflects the radiosensitivity of the cell 


\section{Radiosurgery in the treatment of craniopharyngiomas}

TABLE 2: Summary of characteristics of patients who underwent CyberKnife SRS for residual craniopharyngiomas, $2000-2007^{*}$

\begin{tabular}{|c|c|c|c|c|c|c|c|c|c|c|c|}
\hline $\begin{array}{c}\text { Case } \\
\text { No. }\end{array}$ & $\begin{array}{c}\text { Age } \\
\text { (yrs), } \\
\text { Sex }\end{array}$ & Presentation & $\begin{array}{c}\text { No. } \\
\text { of } \\
\text { Ops }\end{array}$ & $\begin{array}{l}\text { Post- } \\
\text { op } \\
\text { RT }\end{array}$ & $\begin{array}{c}\text { Pre-SRS } \\
\text { Visual } \\
\text { Problems }\end{array}$ & $\begin{array}{l}\text { Pre-SRS } \\
\text { Endocrine } \\
\text { Problems }\end{array}$ & $\begin{array}{l}\text { No. of } \\
\text { Frac- } \\
\text { tions }\end{array}$ & $\begin{array}{c}\text { Treatment } \\
\text { Dose } \\
\text { (Gy) }\end{array}$ & $\begin{array}{c}\text { Mean } \\
\text { Isodose } \\
\text { Line (\%) }\end{array}$ & $\begin{array}{l}\text { Max } \\
\text { Dose } \\
\text { (Gy) }\end{array}$ & $\begin{array}{c}\text { Target } \\
\text { Volume } \\
\left(\mathrm{cm}^{3}\right)\end{array}$ \\
\hline 1 & $32, \mathrm{~F}$ & HA \& VFD & 3 & no & yes & no & 3 & 18 & 75 & 22.5 & 1.4 \\
\hline 2 & $16, F$ & HA \& VFD & 2 & yes & yes & no & 3 & 19.5 & 80 & 24.3 & 12.7 \\
\hline 3 & $71, \mathrm{M}$ & N\&V \& VFD & 1 & no & yes & no & 3 & 20 & 74 & 26.6 & 0.7 \\
\hline 4 & $45, \mathrm{~F}$ & hypopit \& VFD & 2 & no & yes & yes & 5 & 20 & 77 & 26 & 1.1 \\
\hline $5 \dagger$ & $43, M$ & hypopit \& VFD & 2 & no & yes & yes & 10 & 38 & 72 & 42.1 & 26.3 \\
\hline 6 & $17, \mathrm{~F}$ & HA, VFD & 1 & no & yes & no & 4 & 20 & 77 & 24.1 & 1.2 \\
\hline 7 & $13, \mathrm{~F}$ & WG \& hypopit & 3 & no & no & yes & 5 & 27.5 & 71 & 36.7 & 10.1 \\
\hline 8 & $20, M$ & VFD \& hypopit & 1 & no & yes & yes & 5 & 25 & 76 & 30.5 & 0.3 \\
\hline 9 & $39, \mathrm{~F}$ & HA \& VFD & 2 & no & yes & no & 5 & 25 & 67 & 33.3 & 6.3 \\
\hline 10 & $37, \mathrm{M}$ & HA \& VFD & 3 & no & yes & no & 5 & 25 & 73 & 31.7 & 3.8 \\
\hline 11 & $46, M$ & hypopit \& VFD & 1 & no & yes & yes & 5 & 25 & 80 & 31.3 & 1.3 \\
\hline
\end{tabular}

* HA = headache; hypopit = hypopituitarism; N \& V = nausea and vomiting; RT = radiation therapy; WG = weight gain.

† Patient underwent stereotactic radiotherapy.

TABLE 3: Summary of 11 patients and treatment planning characteristics included in analysis

\begin{tabular}{|c|c|}
\hline Characteristic & Value \\
\hline \multicolumn{2}{|l|}{$\operatorname{sex}$} \\
\hline male & 5 \\
\hline female & 6 \\
\hline mean age in yrs (range) & $34.5(13-71)$ \\
\hline \multicolumn{2}{|l|}{ no. of previous surgeries } \\
\hline 1 & 4 \\
\hline 2 & 4 \\
\hline 3 & 3 \\
\hline no. of previous radiotherapies & 1 \\
\hline \multicolumn{2}{|l|}{ extent of last resection } \\
\hline complete & 1 \\
\hline subtotal & 10 \\
\hline \multicolumn{2}{|l|}{ site of residual or recurrent tumor } \\
\hline intrasellar & 1 \\
\hline suprasellar & 9 \\
\hline both & 1 \\
\hline no. against optic apparatus & 8 \\
\hline no. against pituitary stalk or gland & 1 \\
\hline no. against both & 2 \\
\hline \multicolumn{2}{|l|}{ no. of CyberKnife sessions } \\
\hline 3 & 3 \\
\hline 4 & 1 \\
\hline 5 & 6 \\
\hline 10 & 1 \\
\hline mean target volume in $\mathrm{cm}^{3}$ (range) & $6(0.3-26.3)$ \\
\hline mean marginal dose in Gy (range) & $21.6(18-38)$ \\
\hline mean maximal dose in Gy (range) & $29.9(24.1-42.1)$ \\
\hline
\end{tabular}

being exposed; the higher the $\alpha / \beta$ ratio, the more radiosensitive the cell. Various studies have shown that cranial nerve neuropathies occurred in 1 to $3 \%$ of cases when the brainstem was irradiated to 12 to $13 \mathrm{~Gy}$. We have chosen to use a fractionation scheme when the single fraction dose exceeds 13 Gy to more than $20 \%$ of the brainstem, as is often encountered in craniopharyngiomas. In addition, we limit the single fraction dose to the optic apparatus to $<10$ Gy by utilizing a fractionation scheme of 2 to 5 fractions and limiting the exposure to the optic apparatus to $<5$ Gy per fraction. Using these parameters, we have been able to preserve preradiation visual function in $94 \%$ of cases involving perioptic lesions. ${ }^{1}$

The exact $\alpha / \beta$ ratio of craniopharyngiomas is unknown, but others have used a ratio of $2 .^{86} \mathrm{By}$ assuming an $\alpha / \beta$ ratio of 2 , we can calculate that a radiation schedule of $25 \mathrm{~Gy}$ in 5 sessions estimates a single-dose equivalent of $12.3 \mathrm{~Gy}$, a dose that approaches our intended target.

\section{Conclusions}

Optimal management of craniopharyngiomas remains controversial. The often peculiar location of a

\section{TABLE 4: Clinical and radiological outcome after CyberKnife} treatment of residual tumor

\begin{tabular}{ll}
\hline \multicolumn{1}{c}{ Variable } & \multicolumn{1}{c}{ Value } \\
\hline $\begin{array}{l}\text { mean follow-up in mos (range) } \\
\text { tumor size }\end{array}$ & 15.4 (4-64) \\
decreased & 7 \\
stable & 3 \\
increased & 1 (cyst enlargement) \\
no. w/ visual field deterioration & 0 \\
no. w/ endocrine deterioration & 0 \\
\hline
\end{tabular}




\section{A. Veeravagu et al.}

craniopharyngioma implicates vital structures that may be subjected to undue harm after radiotherapy. Thus, a custom multimodality treatment strategy is employed to optimize outcome. Radiotherapy has a definitive role in the treatment of craniopharyngiomas, both as an adjuvant therapy following primary STR and also as a primary treatment for recurrent disease. Our experience demonstrates that multisession therapy may prevent unintended consequences to surrounding optic structures and provide significant disease control. Although further long-term studies are required to fully evaluate clinical outcome, current evidence suggests beneficial results of radiotherapy for craniopharyngiomas.

\section{Disclosure}

Dr. Chang is a shareholder of Accuray, Inc., and is supported in part by a research gift from Robert C. and Jeannette Powell.

Author contributions to the study and manuscript preparation include the following. Conception and design: A Veeravagu, M Lee, SD Chang. Acquisition of data: A Veeravagu, M Lee, SD Chang. Analysis and interpretation of data: A Veeravagu, M Lee, B Jiang, SD Chang. Drafting the article: A Veeravagu, M Lee, B Jiang, SD Chang. Critically revising the article: A Veeravagu, B Jiang, SD Chang. Reviewed final version of the manuscript and approved it for submission: A Veeravagu, SD Chang. Statistical analysis: A Veeravagu, SD Chang. Administrative/technical/material support: A Veeravagu, SD Chang. Study supervision: A Veeravagu, SD Chang.

\section{References}

1. Adler JR Jr, Gibbs IC, Puataweepong P, Chang SD: Visual field preservation after multisession cyberknife radiosurgery for perioptic lesions. Neurosurgery 59:244-254, 2006

2. Agha A, Sherlock M, Brennan S, O'Connor SA, O'Sullivan E, Rogers B, et al: Hypothalamic-pituitary dysfunction after irradiation of nonpituitary brain tumors in adults. J Clin Endocrinol Metab 90:6355-6360, 2005

3. Albright AL, Hadjipanayis CG, Lunsford LD, Kondziolka D, Pollack IF, Adelson PD: Individualized treatment of pediatric craniopharyngiomas. Childs Nerv Syst 21:649-654, 2005

4. Amendola BE, Wolf A, Coy SR, Amendola MA: Role of radiosurgery in craniopharyngiomas: a preliminary report. Med Pediatr Oncol 41:123-127, 2003

5. Brada M, Ford D, Ashley S, Bliss JM, Crowley S, Mason M, et al: Risk of second brain tumour after conservative surgery and radiotherapy for pituitary adenoma. BMJ 304:1343-1346, 1992

6. Bunin GR, Surawicz TS, Witman PA, Preston-Martin S, Davis F, Bruner JM: The descriptive epidemiology of craniopharyngioma. J Neurosurg 89:547-551, 1998

7. Cáceres A: Intracavitary therapeutic options in the management of cystic craniopharyngioma. Childs Nerv Syst 21:705718,2005

8. Caldarelli M, di Rocco C, Papacci F, Colosimo C Jr: Management of recurrent craniopharyngioma. Acta Neurochir (Wien) 140:447-454, 1998

9. Caldarelli M, Massimi L, Tamburrini G, Cappa M, Di Rocco C: Long-term results of the surgical treatment of craniopharyngioma: the experience at the Policlinico Gemelli, Catholic University, Rome. Childs Nerv Syst 21:747-757, 2005

10. Chiou SM, Lunsford LD, Niranjan A, Kondziolka D, Flickinger JC: Stereotactic radiosurgery of residual or recurrent craniopharyngioma, after surgery, with or without radiation therapy. Neuro-oncol 3:159-166, 2001

11. Chung WY, Pan DH, Shiau CY, Guo WY, Wang LW: Gamma knife radiosurgery for craniopharyngiomas. J Neurosurg 93 (Suppl 3):47-56, 2000

12. Combs SE, Thilmann C, Huber PE, Hoess A, Debus J, SchulzErtner D: Achievement of long-term local control in patients with craniopharyngiomas using high precision stereotactic radiotherapy. Cancer 109:2308-2314, 2007

13. Constine LS, Randall SH, Rubin P, McDonald J: Craniopharyngiomas: fluctuation in cyst size following surgery and radiation therapy. Neurosurgery 24:53-59, 1989

14. Darzy KH, Shalet SM: Hypopituitarism after cranial irradiation. J Endocrinol Invest 28 (5 Suppl):78-87, 2005

15. Derrey S, Blond S, Reyns N, Touzet G, Carpentier P, Gauthier $\mathrm{H}$, et al: Management of cystic craniopharyngiomas with stereotactic endocavitary irradiation using colloidal 186Re: a retrospective study of 48 consecutive patients. Neurosurgery 63:1045-1053, 2008

16. Douglas BG, Fowler JF: The effect of multiple small doses of $\mathrm{x}$ rays on skin reactions in the mouse and a basic interpretation. Radiat Res 66:401-426, 1976

17. Duff JM, Meyer FB, Ilstrup DM, Laws ER Jr, Schleck C, Scheithauer BW: Long-term outcomes for surgically resected craniopharyngiomas. Neurosurgery 46:291-305, 2000

18. Fahlbusch R, Honegger J, Paulus W, Huk W, Buchfelder M: Surgical treatment of craniopharyngiomas: experience with 168 patients. J Neurosurg 90:237-250, 1999

19. Fischer EG, Welch K, Shillito J Jr, Winston KR, Tarbell NJ: Craniopharyngiomas in children. Long-term effects of conservative surgical procedures combined with radiation therapy. J Neurosurg 73:534-540, 1990

20. Fisher BJ, Gaspar LE, Noone B: Radiation therapy of pituitary adenoma: delayed sequelae. Radiology 187:843-846, 1993

21. Fisher PG, Jenab J, Gopldthwaite PT, Tihan T, Wharam MD, Foer DR, et al: Outcomes and failure patterns in childhood craniopharyngiomas. Childs Nerv Syst 14:558-563, 1998

22. Fitzek MM, Linggood RM, Adams J, Munzenrider JE: Combined proton and photon irradiation for craniopharyngioma: long-term results of the early cohort of patients treated at Harvard Cyclotron Laboratory and Massachusetts General Hospital. Int J Radiat Oncol Biol Phys 64:1348-1354, 2006

23. Flickinger JC, Lunsford LD, Singer J, Cano ER, Deutsch M: Megavoltage external beam irradiation of craniopharyngiomas: analysis of tumor control and morbidity. Int J Radiat Oncol Biol Phys 19:117-122, 1990

24. Garnett MR, Puget S, Grill J, Sainte-Rose C: Craniopharyngioma. Orphanet J Rare Dis 2:18, 2007

25. Garrè ML, Cama A: Craniopharyngioma: modern concepts in pathogenesis and treatment. Curr Opin Pediatr 19:471-479, 2007

26. Giller CA, Berger BD, Pistenmaa DA, Sklar F, Weprin B, Shapiro $\mathrm{K}$, et al: Robotically guided radiosurgery for children. Pediatr Blood Cancer 45:304-310, 2005

27. Girkin CA, Comey CH, Lunsford LD, Goodman ML, Kline LB: Radiation optic neuropathy after stereotactic radiosurgery. Ophthalmology 104:1634-1643, 1997

28. Gopalan R, Dassoulas K, Rainey J, Sherman JH, Sheehan JP: Evaluation of the role of Gamma Knife surgery in the treatment of craniopharyngiomas. Neurosurg Focus 24(5):E5, 2008

29. Gupta DK, Ojha BK, Sarkar C, Mahapatra AK, Sharma BS, Mehta VS: Recurrence in pediatric craniopharyngiomas: analysis of clinical and histological features. Childs Nerv Syst 22:50-55, 2006

30. Habrand JL, Ganry O, Couanet D, Rouxel V, Levy-Piedbois C, Pierre-Kahn A, et al: The role of radiation therapy in the management of craniopharyngioma: a 25-year experience and review of the literature. Int J Radiat Oncol Biol Phys 44:255-263, 1999

31. Haupt R, Magnani C, Pavanello M, Caruso S, Dama E, Garrè 
ML: Epidemiological aspects of craniopharyngioma. J Pediatr Endocrinol Metab 19 (Suppl 1):289-293, 2006

32. Hetelekidis S, Barnes PD, Tao ML, Fischer EG, Schneider L, Scott RM, et al: 20-year experience in childhood craniopharyngioma. Int J Radiat Oncol Biol Phys 27:189-195, 1993

33. Hoffman HJ, De Silva M, Humphreys RP, Drake JM, Smith ML, Blaser SI: Aggressive surgical management of craniopharyngiomas in children. J Neurosurg 76:47-52, 1992

34. Honegger J, Barocka A, Sadri B, Fahlbusch R: Neuropsychological results of craniopharyngioma surgery in adults: a prospective study. Surg Neurol 50:19-29, 1998

35. Honegger J, Buchfelder M, Fahlbusch R: Surgical treatment of craniopharyngiomas: endocrinological results. J Neurosurg 90:251-257, 1999

36. Honegger J, Tatagiba M: Craniopharyngioma surgery. Pituitary 11:361-373, 2008

37. Hoshi M, Hayashi T, Kagami H, Murase I, Nakatsukasa M: Late bilateral temporal lobe necrosis after conventional radiotherapy. Neurol Med Chir (Tokyo) 43:213-216, 2003

38. Isaac MA, Hahn SS, Kim JA, Bogart JA, Chung CT: Management of craniopharyngioma. Cancer J 7:516-520, 2001

39. Jane JA Jr, Laws ER: Craniopharyngioma. Pituitary 9:323326, 2006

40. Jones B, Dale RG, Finst P, Khaksar SJ: Biological equivalent dose assessment of the consequences of hypofractionated radiotherapy. Int J Radiat Oncol Biol Phys 47:1379-1384, 2000

41. Jose CC, Rajan B, Ashley S, Marsh H, Brada M: Radiotherapy for the treatment of recurrent craniopharyngioma. Clin Oncol (R Coll Radiol) 4:287-289, 1992

42. Julow J, Backlund EO, Lányi F, Hajda M, Bálint K, Nyáry I, et al: Long-term results and late complications after intracavitary yttrium-90 colloid irradiation of recurrent cystic craniopharyngiomas. Neurosurgery 61:288-296, 2007

43. Kalapurakal JA, Goldman S, Hsieh YC, Tomita T, Marymont $\mathrm{MH}$ : Clinical outcome in children with craniopharyngioma treated with primary surgery and radiotherapy deferred until relapse. Med Pediatr Oncol 40:214-218, 2003

44. Kalapurakal JA, Goldman S, Hsieh YC, Tomita T, Marymont $\mathrm{MH}$ : Clinical outcome in children with recurrent craniopharyngioma after primary surgery. Cancer J 6:388-393, 2000

45. Karavitaki N, Brufani C, Warner JT, Adams CB, Richards P, Ansorge O, et al: Craniopharyngiomas in children and adults: systematic analysis of 121 cases with long-term follow-up. Clin Endocrinol (Oxf) 62:397-409, 2005

46. Karavitaki N, Cudlip S, Adams CB, Wass JA: Craniopharyngiomas. Endocr Rev 27:371-397, 2006

47. Kobayashi T: Long-term results of gamma knife radiosurgery for 100 consecutive cases of craniopharyngioma and a treatment strategy. Prog Neurol Surg 22:63-76, 2009

48. Kobayashi T, Kida Y, Mori Y, Hasegawa T: Long-term results of gamma knife surgery for the treatment of craniopharyngioma in 98 consecutive cases. J Neurosurg 103 (6 Suppl): 482-488, 2005

49. Kramer S, Southard M, Mansfield CM: Radiotherapy in the management of craniopharyngiomas: further experiences and late results. Am J Roentgenol Radium Ther Nucl Med 103:44-52, 1968

50. Kuratsu J, Ushio Y: Epidemiological study of primary intracranial tumors in childhood. A population-based survey in Kumamoto Prefecture, Japan. Pediatr Neurosurg 25:240247, 1996

51. Leber KA, Berglöff J, Pendl G: Dose-response tolerance of the visual pathways and cranial nerves of the cavernous sinus to stereotactic radiosurgery. J Neurosurg 88:43-50, 1998

52. Lee M, Kalani MY, Cheshier S, Gibbs IC, Adler JR, Chang SD: Radiation therapy and CyberKnife radiosurgery in the management of craniopharyngiomas. Neurosurg Focus 24(5):E4, 2008
53. Luu QT, Loredo LN, Archambeau JO, Yonemoto LT, Slater JM, Slater JD: Fractionated proton radiation treatment for pediatric craniopharyngioma: preliminary report. Cancer $\mathbf{J}$ 12:155-159, 2006

54. McCollough WM, Marcus RB Jr, Rhoton AL Jr, Ballinger WE, Million RR: Long-term follow-up of radiotherapy for pituitary adenoma: the absence of late recurrence after greater than or equal to 4500 cGy. Int J Radiat Oncol Biol Phys 21:607-614, 1991

55. McCord MW, Buatti JM, Fennell EM, Mendenhall WM, Marcus RB Jr, Rhoton AL, et al: Radiotherapy for pituitary adenoma: long-term outcome and sequelae. Int J Radiat Oncol Biol Phys 39:437-444, 1997

56. Merchant TE, Kiehna EN, Sanford RA, Mulhern RK, Thompson SJ, Wilson MW, et al: Craniopharyngioma: the St. Jude Children's Research Hospital experience 1984-2001. Int J Radiat Oncol Biol Phys 53:533-542, 2002

57. Minamida Y, Mikami T, Hashi K, Houkin K: Surgical management of the recurrence and regrowth of craniopharyngiomas. J Neurosurg 103:224-232, 2005

58. Minniti G, Esposito V, Amichetti M, Enrici RM: The role of fractionated radiotherapy and radiosurgery in the management of patients with craniopharyngioma. Neurosurg Rev 32:125-132, 2009

59. Minniti G, Saran F, Traish D, Soomal R, Sardell S, Gonsalves A, et al: Fractionated stereotactic conformal radiotherapy following conservative surgery in the control of craniopharyngiomas. Radiother Oncol 82:90-95, 2007

60. Miyazaki ST, TakusagawaY, Fukushima T: Multisession cyberknife radiosurgery in the management of craniopharyngioma. Presented at the Eighth Annual CyberKnife Users' Meeting, Hollywood, Florida, Saturday, February 7, 2009 (Abstract). www.cksociety.org/CKSociety/document/ docdownload.aspx?docid=65. [Accessed February 26, 2010]

61. Mokry M: Craniopharyngiomas: a six year experience with Gamma Knife radiosurgery. Stereotact Funct Neurosurg 72 (Suppl 1):140-149, 1999

62. Moon SH, Kim IH, Park SW, Kim I, Hong S, Park CI, et al: Early adjuvant radiotherapy toward long-term survival and better quality of life for craniopharyngiomas - a study in single institute. Childs Nerv Syst 21:799-807, 2005

63. Movsas B, Movsas TZ, Steinberg SM, Okunieff P: Long-term visual changes following pituitary irradiation. Int J Radiat Oncol Biol Phys 33:599-605, 1995

64. Murphy MJ, Chang SD, Gibbs IC, Le QT, Hai J, Kim D, et al: Patterns of patient movement during frameless image-guided radiosurgery. Int J Radiat Oncol Biol Phys 55:1400-1408, 2003

65. Pemberton LS, Dougal M, Magee B, Gattamaneni HR: Experience of external beam radiotherapy given adjuvantly or at relapse following surgery for craniopharyngioma. Radiother Oncol 77:99-104, 2005

66. Pham CJ, Chang SD, Gibbs IC, Jones P, Heilbrun MP, Adler JR Jr: Preliminary visual field preservation after staged CyberKnife radiosurgery for perioptic lesions. Neurosurgery 54:799-812, 2004

67. Pollock BE, Lunsford LD, Kondziolka D, Levine G, Flickinger JC: Phosphorus-32 intracavitary irradiation of cystic craniopharyngiomas: current technique and long-term results. Int J Radiat Oncol Biol Phys 33:437-446, 1995

68. Prasad D, Steiner M, Steiner L: Gamma knife surgery for craniopharyngioma. Acta Neurochir (Wien) 134:167-176, 1995

69. Rajan B, Ashley S, Gorman C, Jose CC, Horwich A, Bloom HJ, et al: Craniopharyngioma-a long-term results following limited surgery and radiotherapy. Radiother Oncol 26:1-10, 1993

70. Rajan B, Ashley S, Thomas DG, Marsh H, Britton J, Brada M: Craniopharyngioma: improving outcome by early recognition 


\section{A. Veeravagu et al.}

and treatment of acute complications. Int J Radiat Oncol Biol Phys 37:517-521, 1997

71. Regine WF, Mohiuddin M, Kramer S: Long-term results of pediatric and adult craniopharyngiomas treated with combined surgery and radiation. Radiother Oncol 27:13-21, 1993

72. Rickert CH, Paulus W: Epidemiology of central nervous system tumors in childhood and adolescence based on the new WHO classification. Childs Nerv Syst 17:503-511, 2001

73. Sachs RK, Brenner DJ: Solid tumor risks after high doses of ionizing radiation. Proc Natl Acad Sci U S A 102:1304013045, 2005

74. Schubert T, Trippel M, Tacke U, van Velthoven V, Gumpp V, Bartelt S, et al: Neurosurgical treatment strategies in childhood craniopharyngiomas: is less more? Childs Nerv Syst 25:1419-1427, 2009

75. Selch MT, DeSalles AA, Wade M, Lee SP, Solberg TD, Wallace RE, et al: Initial clinical results of stereotactic radiotherapy for the treatment of craniopharyngiomas. Technol Cancer Res Treat 1:51-59, 2002

76. Shi XE, Wu B, Fan T, Zhou ZQ, Zhang YL: Craniopharyngioma: surgical experience of 309 cases in China. Clin Neurol Neurosurg 110:151-159, 2008

77. Shi XE, Wu B, Zhou ZQ, Fan T, Zhang YL: Microsurgical treatment of craniopharyngiomas: report of 284 patients. Chin Med J (Engl) 119:1653-1663, 2006

78. Stafford SL, Pollock BE, Leavitt JA, Foote RL, Brown PD, Link MJ, et al: A study on the radiation tolerance of the optic nerves and chiasm after stereotactic radiosurgery. Int J Radiat Oncol Biol Phys 55:1177-1181, 2003

79. Stripp DC, Maity A, Janss AJ, Belasco JB, Tochner ZA, Goldwein JW, et al: Surgery with or without radiation therapy in the management of craniopharyngiomas in children and young adults. Int J Radiat Oncol Biol Phys 58:714-720, 2004

80. Thompson D, Phipps K, Hayward R: Craniopharyngioma in childhood: our evidence-based approach to management. Childs Nerv Syst 21:660-668, 2005

81. Timmerman R, Papiez L, Suntharalingam M: Extracranial stereotactic radiation delivery: expansion of technology beyond the brain. Technol Cancer Res Treat 2:153-160, 2003

82. Tomita T, Bowman RM: Craniopharyngiomas in children: surgical experience at Children's Memorial Hospital. Childs Nerv Syst 21:729-746, 2005

83. Tsang RW, Brierley JD, Panzarella T, Gospodarowicz MK,
Sutcliffe SB, Simpson WJ: Radiation therapy for pituitary adenoma: treatment outcome and prognostic factors. Int J Radiat Oncol Biol Phys 30:557-565, 1994

84. Ulfarsson E, Lindquist C, Roberts M, Rähn T, Lindquist M, Thorén M, et al: Gamma knife radiosurgery for craniopharyngiomas: long-term results in the first Swedish patients. J Neurosurg 97 (5 Suppl):613-622, 2002

85. Van Effenterre R, Boch AL: Craniopharyngioma in adults and children: a study of 122 surgical cases. J Neurosurg 97:3-11, 2002

86. Varlotto JM, Flickinger JC, Kondziolka D, Lunsford LD, Deutsch M: External beam irradiation of craniopharyngiomas: long-term analysis of tumor control and morbidity. Int J Radiat Oncol Biol Phys 54:492-499, 2002

87. Vinchon M, Dhellemmes P: Craniopharyngiomas in children: recurrence, reoperation and outcome. Childs Nerv Syst 24:211-217, 2008

88. Voges J, Sturm V, Lehrke R, Treuer H, Gauss C, Berthold F: Cystic craniopharyngioma: long-term results after intracavitary irradiation with stereotactically applied colloidal betaemitting radioactive sources. Neurosurgery 40:263-270, 1997

89. Yaşargil MG, Curcic M, Kis M, Siegenthaler G, Teddy PJ, Roth P: Total removal of craniopharyngiomas. Approaches and long-term results in 144 patients. J Neurosurg 73:3-11, 1990

90. Yomo S, Hayashi M, Chernov M, Tamura N, Izawa M, Okada $Y$, et al: Stereotactic radiosurgery of residual or recurrent craniopharyngioma: new treatment concept using Leksell gamma knife model $\mathrm{C}$ with automatic positioning system. Stereotact Funct Neurosurg 87:360-367, 2009

91. Yu X, Liu Z, Li S: Combined treatment with stereotactic intracavitary irradiation and gamma knife surgery for craniopharyngiomas. Stereotact Funct Neurosurg 75:117-122, 2000

92. Zuccaro G: Radical resection of craniopharyngioma. Childs Nerv Syst 21:679-690, 2005

Manuscript submitted December 15, 2009.

Accepted February 3, 2010.

Address correspondence to: Steven D. Chang, M.D., Stanford University Hospital, 300 Pasteur Drive, Stanford, California 94305. email: sdchang@stanford.edu. 